\title{
Status of lifelong learning in Guayaquil, Ecuador
}

\section{Estado del aprendizaje permanente en Guayaquil, Ecuador}

\author{
María Eugenia Delgado Rovayo \\ Universidad de Guayaquil, Ecuador \\ Andrés Alberto Chávez Eras \\ Universidad Internacional del Ecuador, Ecuador
}

Autor para correspondencia: maricucha.delgado@gmail.com

Fecha de recepción: 30 de Agosto de 2016 - Fecha de aceptación: 25 de Octubre de 2016

\begin{abstract}
Resumen
Con el fin de proporcionar algún contexto para el estado actual del aprendizaje permanente en Guayaquil, los autores presentarán primero información sobre el aspecto político de la educación y el estado de la educación en la ciudad. Luego, los autores explorarán el concepto de aprendizaje permanente y definirán sus principios para el propósito de esta investigación. Por último, los autores explicarán la asociación que existe entre la Municipalidad de Guayaquil y una organización no gubernamental y evaluarán un programa social que han iniciado y mantenido, con el objetivo de promover el aprendizaje permanente entre los ciudadanos de Guayaquil.
\end{abstract}

Palabras claves: aprendizaje permanente; educación y desarrollo

\begin{abstract}
In order to provide some context for the current state of lifelong learning in Guayaquil, the authors will first present information regarding the political aspect of education and the state of education in the city. Then, the authors will explore the concept of lifelong learning and define its principles for the purpose of this research. Lastly, the authors will explain the partnership that exists between the Municipality of Guayaquil and a non-governmental organization, and evaluate a social program that they have initiated and sustained, which aims to promote lifelong learning among the citizens of Guayaquil.
\end{abstract}

Key words: lifelong-learning; education; development 


\section{Introduction}

Education is an empowering force that provides a space where people can develop their capabilities and explore their possibilities. This type of growth through education should extend beyond formal classrooms into every facet of human life, from birth to death. Lifelong learning is a vital aspect of the continued progress and development of citizens, as well as nations. It is through lifelong learning that citizens of developing nations become enabled to enact the changes that can increase the potential for progress in their nation. Despite the importance of lifelong learning, the federal government of Ecuador has yet to contribute to lifelong learning programs in the country; however, the local government in Guayaquil and non-governmental organizations, as well as private enterprises, have partnered in an effort to extend the opportunity for lifelong learning to the citizens of Guayaquil.

In order to provide some context for the current state of lifelong learning in Guayaquil, the authors will first present information regarding the political aspect of education and the state of education in the city. Then, the authors will explore the concept of lifelong learning and define its principles for the purpose of this research. Lastly, the authors will explain the partnership that exists between the Municipality of Guayaquil and a non-governmental organization, and evaluate a social program that they have initiated and sustained, which aims to promote lifelong learning among the citizens of Guayaquil.

\section{Social and Political Antecedents in Guayaquil}

Guayaquil is Ecuador's main port city with the highest population and strong commercial, financial and touristic activity. Its human development indicators are among the best in the country; however, when compared to other Latin American cities, it is evident that its development remains unequal and poor. The first documented civil society in Guayaquil was organized by a group of philanthropists in the late 1880s. The organization was run by wealthy people with social consciousness, who donated both their time and money to help the impoverished people who did not receive any attention or aid from the State.

Between 1950 and 2001, Guayaquil's population grew by 7.7\%. The 1950 census indicated a population of 258,966 inhabitants while the INEC 2001 (Instituto Nacional de Estadisticas y Censo) census gave a total of 1,985,249 inhabitants. This excessive increase in population led to inadequate basic infrastructure, social problems and unplanned housing settlements. Migration of people from diverse ethnic and regional backgrounds resulted in a city of great cultural diversity that was difficult to manage in terms of organization and integration. The INEC 2001 census revealed that $52.6 \%$ of the population lived in poverty and $23.1 \%$ lived in extreme poverty.

The financial crisis of the 1990s had negative effects on the access and quality of education, especially on the poorest population. Social indicators revealed that youth had poor access to information about health and sexuality. This led to an increase in teenage pregnancy in girls between 15 and 19 years of age from $7.9 \%$ in 1994 to $9.8 \%$ in 1999 . These young mothers and their children were vulnerable to health risks, as well as limitations in their development and worsening of their socio-economic situation. The number of children under the age of five that 
attended day care centers increased to $9 \%$ by the year 2000 ; however, only $3.9 \%$ of caregivers had participated in training programs on childcare.

There are additional issues that needed to be addressed. Families of handicapped children, who need special care, do not always know what to do or where to go for medical attention and counseling. Domestic violence is another major problem for Ecuadorian society, especially for women and children. According to INEC's 2001 survey, 32\% parents have abused their children and $42 \%$ of women have been battered. This has contributed to several social issues, including inequality, exclusion, poor self-esteem, poor living conditions and, unemployment.

\section{History of the State of Education in Ecuador}

From the 1980s to the beginning of 2000, the quality of education was not a priority on the Ecuadorian agenda. The budget was cut, there were no state interventions, and no efforts were made to improve the quality of education available to students. The social and educational impact of schools degraded across all levels; initial, elementary, high school and higher education. During this period of time, many neoliberal regulations were imposed, prioritizing the free market and private enterprise. This resulted in an increase of private schools, which served as a remedy for students of higher socio-economic classes but not for the poorest class who could not afford to pay high amounts of money for private education.

The Ecuadorian Constitution (2008) states that education is a right and establishes citizens' equal opportunities and social inclusion as main elements for having proper living conditions. It also states that education should focus on human beings, promoting gender equality, justice, critical thinking, autonomy, and the development of skills needed in order to create and work. Since 2007, the government of Ecuador has been working to improve the quality of its educational system. Educational policies were included in the Plan Nacional de Desarrollo (National Development Plan) for 2007-2013, which is a document that sets the governance principles and outlines the path that guides the government's work. Since 2008, the government has been implementing development policies that are included in the above mentioned Plan, as well as the Plan Nacional del Buen Vivir (National Plan for Well Living). This Plan, which is for 2014-2017, is not only a tool for social change but one that guides the transformation of the country in areas of development and productivity, health, energy and, especially education, which is the main objective in the development of human talent. This document defends the idea of development based on the quality of life and freedom of human beings, and not merely on money-making activities.

Since the implementation of these plans, a wave of educational reforms has been underway. This represents an encouraging future for Ecuadorian education and its citizens. A new educational regulatory framework, Ley Intercultural de Educacion (Intercultural Law of Education) was approved in 2011. This law, calls for free admission for students, the revalorization of the teaching profession, curricula revision, administrative reorganization of schools, improved infrastructure and equipment, and above all enhanced learning for students, based on quality education for all. Reforms include higher wages for teachers, upgrading seminars, and the provision of meals and textbooks for children. At the higher education level, another legal framework, Ley Organica de Educacion Superior (Organic Law of Higher 
Education) was approved to evaluate universities and careers. Teachers are now required to have a Masters degree and a full-time dedication to teaching and research.

These changes represent progress in terms of Ecuador's education system, which is vital to the country's development. According to Walker (2012), "Education is a crucial element in having a good life... and it has an instrumental value in generating economic opportunities and achieving human rights (p. 181). However, there are still many improvements that need to be made to the education system. One area that is lacking in the current system is an emphasis on lifelong learning. The second objective of the National Development Plan relates to the improvement of citizens' capabilities and their potential, and states that "quality education favours the acquisition of knowledge for life and favours individual and social achievements." This objective has not yet been pursued in terms of a strong orientation policy in lifelong learning. It will be important for the government of Ecuador to make changes in order to work towards fulfilling this objective due to the evidence that lifelong learning is a crucial aspect of human development, as will be discussed in continuation.

\section{Lifelong Learning: Literature Review}

Education involves different processes that contribute to the formation of human beings, from initial education to college and postgraduate years. However, a key element in the comprehensive formation chain of the individual is often overlooked, which is the ongoing learning process that is required in order to live in a society that is in constant evolution.

The term lifelong learning refers to learning throughout life in both a formal and informal manner. Continuing education after formal schooling ends is vital for individuals for several reasons; the Council of Europe (1970) explained that "all elements or knowledge learned in school or college soon require an update due to the rising amounts of new information" (p. 2223). Individuals consistently face new challenges in a world that is perpetually changing, and updated knowledge is an imperative for survival in the workplace or any other setting.

Additionally, in order for individuals to progress, they must change, and one way that an individual changes is through learning. As Jarvis (2006) stated, "Human learning is the combination of processes whereby the whole person - body and mind - experiences a social situation, the perceived content of which is then transformed cognitively, emotively, or practically and integrated into the person's individual biography resulting in a changed person" (p. 206).

Individual learning and change contribute to national change and progress. David Blunkett, former Secretary of State for Education and Employment in the United Kingdom, stated, "Learning is the key to prosperity - for each of us as individuals, as well as for the nation as a whole (as cited in Tight, 1998, p. 256). Thus, lifelong learning is important not only for the individual, but for the nations comprised of these individuals. As citizens of a nation further their learning, the knowledge that they gain, as well as their enhanced personal satisfaction and prosperity, contribute to the development of the nation in which they live, work, and serve. 
The idea of lifelong learning as an important facet of human development is not a new one. According to Dave (1976), the authors of the 1919 Report of the British Ministry of Reconstruction "deemed necessary lifelong education but unfortunately their plans were never actualized" (p. 132). It wasn't until the 1960s, when educational crisis and socioeconomic changes hit Europe, that the first policies were implemented for education across the lifespan. The decay of the educational system was regarded as a humanistic issue by UNESCO, a political problem by the Council of Europe, and a socioeconomic issue by the OECD (Centeno, 2011, p. 141). These perceived causes became the fundamental reasons for which the education across the lifespan policies were designed. The policies were conceived as education for adults that would address social integration, welfare, and the inability of the education system to meet market demands.

In 1972, UNESCO published the Faure Report, which recognized the importance of lifelong learning for each citizen in terms of personal development. The report proposed "lifelong education as the master concept for educational policies in the years to come for both developed and developing countries" (Faure, et. al, 1972). Then, 28 years later, UNESCO published the Delors report, which stated that the "concept of lifelong education had to be updated to meet new challenges and adapt to changes" (Delors, et. al, 2000). Theories of lifelong learning and the policies that attempt to act on those theories must evolve alongside the information and resources that become available over time; in effect, lifelong learning is as active and transformative as the individuals who pursue it.

There are conflicting perspectives regarding the benefits of lifelong learning as it is currently being implemented. According to Professor Melanie Walker (2012), some policies promoting lifelong learning do not increase individual agency or promote good living; rather, in some instances, a policy can "have a lack of social vision as it is built for service to employers" (p. 181). Another professor of higher education, Professor Malcolm Tight (1998), added that while the purpose of lifelong learning is to empower individuals and nations, programs are often implemented with "a strong sense of expectation, even compulsion, with emphasis given to vocational forms of study and participation" (p. 9). These criticisms present a potential issue within lifelong learning, which is that policies may cater more towards what employers want their employees to learn, rather than the knowledge and skills that are most beneficial to individuals in terms of their human development. It will be important for those involved in the lifelong learning process to remember all the elements of learning as described by the European Commission on Lifelong Learning (2000), which are "all learning activity undertaken throughout life, with the aim of improving knowledge, skills and competencies with a personal, civic, social and/or employment related perspective" (p. 29). Focusing too much on employment and neglecting the other spheres of learning leads to unbalanced policies that fail to profit the individual across other areas of life.

\section{Government and Civil Society in Ecuador}

\section{Decentralized Administration of the Municipality of Guayaquil}

Since 1992, the Municipality of Guayaquil has operated under a concept of local public management that favors efficiency based on long-term planning. This new vision and 
management is in accordance with the Ley Especial de Descentralizacion del Estado y Participacion Social (Special law of Decentralization of the State and Social Participation). Article 3 of the law sets new guidelines for the transference of financial resources and responsibilities from the state to the municipalities, especially in health, education, and welfare issues. It aims to decentralize political power and decision-making. It also sets the framework for the planning of programs aimed for the development of the cities and the well-being of its citizens. This allows for a partnership between civil society and private enterprises for an efficient and diligent execution of the programmes aimed towards purposeful learning activities, such as crafts, technology, leadership, foreign languages, analytical skills and so on.

Education is a matter of the central government, in terms of administrating initial, elementary, secondary and higher education. However, the local government has slowly taken over this commitment to complement and strengthen the state-dependent educational system and present educational alternatives aimed towards at-risk and in-need populations.

The municipality created the Department of Social Action and Education (DASE) in September 2000. Its mission is to promote and contribute to the human and social development of the citizens and, to improve the quality and standards of living of the population, giving special attention to people facing difficult circumstances.

Surveys were conducted in August 2002 to identify the needs of the population as well as their interests. DASE's educational policies aimed to solve three major problems: persistent inequality, low quality of the education system and lack of programs for people with disabilities. Education was defined as a priority and actions were taken to address the population's needs by providing daycare centers for people with disabilities and homes for the elderly and victims of domestic violence.

\section{Civil Society}

In addition to the municipality, civil society plays an important role in education in Ecuador. Civil societies are valuable because they are separate from economical and political societies; they constitute a more private sphere and allow for various forms of cooperative groups, such as cultural institutions and neighborhood associations (Cohen \& Arato, 1992, p. 143). The World Bank recognizes several forms of civil societies, including community, nongovernmental organizations (NGOs), charitable organizations, labour groups, faith-based organizations and professional associations (World Bank, 2015). These societies are able to make unique contributions to the educational arena because they are "seen as providing potential spaces both for learning free from domination and also engagement with social change" (Murphy, 2001, p. 347).

In the case of Ecuador, the State has opened the frontiers for international institutions to work in favor of human, cultural, educational and social development with a common goal. The government has regulated the operations of non-profit organizations through the Reglamento para Operaciones de Organizaciones Sociales y Ciudades (Regulation for the Operation of Social Organizations and Cities). Article 3 of the aforementioned law states: 
Ecuadorian law supports civil organizations working in favor of the development and satisfaction of human needs and defines these social organizations as forms of society through which individuals, communities, people, etc. have a right to group themselves in an organized and coordinated manner, to set goals and objectives to satisfy human needs for the common good of its members or society in general (http://www.oas.org). Thus, organizations from civil society are encouraged to be proactive in claiming and extending rights and privileges to the citizens of Ecuador.

One such organization, called Fundacion Ecuador was created 23 years ago by a group of business people and professionals from different regions of the country. It is a non-profit, private organization, with no political or religious affiliations, that aims to transmit to the population the elements necessary for sustainable development, with an emphasis on social, education, health and well-being projects. Fundacion Ecuador serves as a liaison between the public and private sectors; the foundation strives to generate discussion and create legal reforms that improve the quality of life of Ecuador's citizens and promote the development of the community (fe.org.ec/historia). Fundacion Ecuador is currently working directly with the Municipality of Ecuador to promote a project called Aprendamos, una oportunidad para superarnos, which is a lifelong learning program that is currently available to the people of Ecuador.

\section{Aprendamos, An Opportunity to Excel}

Aprendamos is the first educational television program in Ecuador implemented in the context of the social and educational policies of the Municipality of Guayaquil through partnerships with the private sector and civil society. The program was officially launched in October 2003 as a response to the needs of marginalized people, both young and old, living in rural as well as densely urban areas. The goal of the program is to improve the quality of life and promote social inclusion for the members of the population that face situations of poverty, exclusion, unemployment and limited access to a relevant and quality education.

Research supports the use of television as a communicational means for education. Palmer (1997) found that "television is drastically underutilized as a teaching tool in countries with education needs" (p. 72). Likewise, the Faure Report (1972) found it "indispensable for all countries, whatever their level of development, to use educational technology and techno principles on a large scale" (p. 35). Television is a device in which millions of families of the lowest income levels invest for entertaining purposes. They may not have a gas stove, but they invest in a television to be informed and entertained. Taking advantage of its widespread use, the executives of Aprendamos believed that it was the best tool to reach the target audience. In addition to the instruction given over the television, registered learners were provided with textbooks and CDs to supplement their learning.

\section{Overview of the Courses and Participants}

It was decided that the contents of the courses should prioritize topics that would encourage students to acquire new knowledge, practices, and attitudes. I will briefly explain two of the courses provided through the program. The first is called Promoting Child Development, and it is targeted towards mothers, caretakers, childcare providers, kindergarten teachers and 
people with a social calling. The purpose is to contribute to the improvement of the quality of family life, especially that of the children, and to promote healthy relationships. Topics of the course include responsible parenting and healthy relationships to decrease family and child violence, among others. Finally, practice requires careful tending and feeding of children, and sharing home duties.

The second course, called Citizenship: an opportunity for all, is aimed at students, adults, neighborhood leaders, non-governmental organization employees and social groups. The purpose is to strengthen the formation of responsible citizens, generating an active and free participation. Contents include organization of communities, operation of local governments and learning of citizens' rights. Practicum requires the learner to incorporate necessary practices in urban life, to organize the community and to be able to represent the community in any setting.

Between the years of 2003 and 2012, there were 894,949 officially registered learners. This figure represents viewers from Guayaquil; however, since the program is broadcasted on an open signal at national level, it is estimated that coverage exceeds 2 million viewers. The percentage of registered female learners is over $64 \%$. Half of the registered viewers are between the ages of 26 and 46 . The number of participants over the age of 53 increased from $9.97 \%$ in 2003 to $14.84 \%$ in 2012.

The program's original target was men and women from densely populated urban areas with no formal or incomplete education; however, in 2003, 71\% of participants had finished high school, and an additional $27 \%$ had finished college. Since then, the program has increased its exposure to the target demographic; in 2012, only 56\% of participants had finished high school, with an additional $17 \%$ that had finished college.

\section{Administration of the Program}

Although the local government is not responsible for formal education in Ecuador, the Municipality of Guayaquil has demonstrated a commitment to planning and executing methods of alternative education aimed at helping those in need. Field (2006) noted that a relationship between government and civic society generally constitutes the core of lifelong learning policies. Aprendamos is no exception, as it benefits from the cooperation of local government, television channels, Fundacion Ecuador, the Chamber of Industries and an Argentinian company called Formar, which specializes in distance education programs. Many other organizations, along with hundreds of individuals devoted to increasing access to education, have helped in the development of the program with their vast knowledge and experience in content, tutoring, admission processes, communication, locations, and television programs.

The authors had the opportunity to interview Roberto Vernimmen, Director of DASE from the Municipality of Guayaquil and Miguel Angel Valdiviezo, Director of Fundacion Ecuador in order to learn more about the program. They agreed that a lot of planning and various strategies have been employed throughout the past years to achieve socially responsible programs. They mentioned that motivation and personal interest in course topics contribute to the full engagement of the learners. The possibility of learning new skills to upgrade job expectation is another aspiration. Both agreed that another factor that accomplished the implementation and 
execution of the program was the integration of a multidisciplinary committee that held weekly meetings to assess the progress of Aprendamos.

The partnership between the Municipality of Ecuador and Fundacion Ecuador has led to the development of a learning community. According to Torres (2005), a learning community is "a human community that works in a determined neighborhood and undertakes a collective compromise committed to obtain the well-being and development of its people" (p. 85). In the case of Aprendamos, the government and civil society share a compromise to improve education, alleviate poverty, and strengthen the autonomy of the people. The partnership between these entities allows the program to reach more people in an effective manner, and it is a positive example of how government and citizens can work together for the amplification of the rights of the people.

\section{Implications of the Aprendamos Program}

The implementation of the Aprendamos program demonstrates the importance of the relationship between the government and civil society in executing lifelong learning programs. This program is successful because it is run by a private, nongovernmental organization that has a positive and collaborative relationship with the local government. The NGO and the government hold weekly meetings in order to coordinate their efforts, and this partnership has been of great benefit to the community. Many people who had desired to further their education but lacked the means and opportunities to do so have benefitted from the accessibility and efficiency of Aprendamos. Since the program includes contributors from different levels of civil society and government, it is able to better represent and serve the various types of individuals that need the service it provides.

Another important aspect of Aprendamos is that it is a bottom-up community initiative. It was developed by citizens who observed problems with the education system in their society and desired to contribute to its improvement. They were well acquainted with the issues that needed to be addressed because they were issues that personally affected their family members, friends, and neighbors. It is imperative that the State find ways to motivate and support more civil society organizations to create and implement programs that foster lifelong learning for the citizens of Ecuador.

There is an initiative called the Open Government Partnership (OGP) that was started in 2011 for the purpose of helping states and civil societies communicate and coordinate for the benefit of their country's development. According to the mission statement, the vision of the OGP is to help governments become more transparent, accountable, and responsive to their citizens, and it aims to support both government and civil society "by elevating open government to the highest levels of political discourse, providing 'cover' for difficult reforms, and creating a supportive community of like-minded reformers from countries around the world" (opengovpartnership.org). Citizens of countries that have joined the initiative are able to develop action plans, join working groups, and share resources with others who are interested in promoting development, both in their own countries and worldwide. For example, a civil society organization interested in launching a program to expand lifelong learning could use the OGP website to propose their action plan, find others that are interested in supporting it and have 
resources that could be of value, and coordinate with the government as to how to initiate and sustain the program. There are currently 66 countries worldwide that participate in the initiative, including the majority of South America, but Ecuador has yet to join. Becoming a part of the OGP would be a positive step towards improving the communication and cooperation between the state and civil societies across several social issues in Ecuador, including lifelong learning.

Additionally, the State could provide incentives for citizens to organize themselves and create programs that contribute to lifelong learning. Many people have good ideas and desires to serve but lack the financial resources to start an organization. The State could set aside money for grants to be awarded to groups with plausible ideas and actionable plans, so that more people have the opportunity to contribute to lifelong learning in the country. They could also provide training programs so that citizens can learn skills or crafts that will help them to become more self-sufficient and fulfilled.

It is clear that the relationship between the state and civil society is important; however, there are several challenges that make it difficult for these entities to function well together. One pertinent challenge is the budget. The government is limited in how much money it can use to support civil society organizations, and many civil society organizations lack the funding necessary to initiate and sustain far-reaching programs. This challenge could be alleviated somewhat if the government would be transparent and forthcoming regarding how much money will be donated to programs; then, civil society will have a better idea of how much money they will need to successfully execute a plan. It will also be imperative for the government to follow through and supply the funding that was initially quoted. Another challenge is the exorbitant amount of paperwork that civil society organizations must submit in order to coordinate with the government, and the government is often inefficient in its handling of said paperwork. The state should better support civil society initiatives by making the paperwork more straightforward and streamlining the processing of the paperwork to make response times faster.

An additional stumbling block is the lack of trust that exists between the government and many nongovernmental organizations. Some NGOs have abused tax exemptions in order to get benefits in the past, and the government has failed to deliver promised funding and resources in other cases. The two entities cannot fully function together if they cannot trust each other, and it is difficult to progress forward when both sides of the relationship are suspiciously glancing to the side. These issues need to be addressed through transparency and accountability, and perhaps new regulations can be formulated to check and balance the relationship between the state and civil society in a fair and neutral manner.

\section{Conclusion}

Lifelong learning is an alternative educational modality aimed not only towards at-risk members of a population, but to all citizens interested in developing and updating their knowledge, acquiring skills and building competencies for individual growth and satisfaction. Current educational policies in Ecuador do not include or promote the concept of lifelong learning; the official bodies merely recognize training and continuing education courses, which are generally taught in higher education institutions. Even in laws and regulations, training is recognized as part of a continuing education process. This was confirmed by a direct inquiry 
made to the Secretaria Nacional de Educacion Superior, Ciencia, Tecnologia e Innovacion (National Secretary of Higher Education, Science, Technology and Innovation).

After reading the National Development Plan 2007-2013 and the National Plan for Well Living 2014-2017, it is obvious that lifelong learning policies are implicit but not officially set out; there is no inclusive and defined policy that establishes a single concept, which makes it difficult for citizens and local governments to implement effective programs that promote lifelong learning. It is advisable that an inclusive public policy be established in order to clearly establish the concept of lifelong learning and illuminate the path towards pursuing it. As the government works to devise this policy, it will be imperative that policymakers keep in mind that "a policy which constructed education as primarily or only for economic growth and productivity would be challenged for its narrowing effects on student learning, identities and achievements" (Walker, 2012, p. 191). Therefore, the proposed policy should include education as a means for well-being and satisfaction, agency in pursuing goals, and innovative methods for learning, in order to cover the active life period of individuals throughout the various stages of life and circumstances that they will face.

Education geared towards lifelong learning should begin when individuals are young; if citizens understand the importance of lifelong learning and feel confident utilizing the resources that are available for their continued progress and enlightenment, they will become active agents that seek further learning without being required to do so. It is imperative that policies are geared towards "equip[ping] young people as confident lifelong learners and democratic citizens" (Walker, 2012, p. 181) so that they will assume responsibility for furthering their learning and development and help others find ways to do the same.

In a recent Global Meeting on Education for All, held in Oman in May 2014, it was mentioned that member countries should include lifelong learning through innovative methods in their education agendas. Currently, civil society and local government are partnering to provide this type of learning for a segment of the population that requires training, whether for a labor occupation, for better parenting or for becoming empowered as active citizens. They are using innovative programs such as educational television and cultural programs. Increased support from the central government would help these organizations to provide more efficient programs to a greater percentage of the population. Membership in the OGP would help facilitate these coordinated efforts, as would a grant program that financially assists groups who wish to contribute to the lifelong learning sector but lack the financial resources to do so.

In moving forward with lifelong learning policies, it will be important for the government and civil society to work together in order to creatively approach the challenges that the people of Ecuador face in terms of furthering their education. According to Bruni, Aguirre, Murillo, Diaz, Fernandez \& Barrios (2008), "A national education project for lifelong learning must necessarily transcend the traditional conceptions of school systems. We must think in systems that promote the education of the whole population using all of society's possible means" (p. 13). Aprendamos is a clear demonstration of a creative commitment made by different societal institutions to provide citizens with lifelong learning opportunities. This program relies on the decentralization of government and political power of the state, the support of civil society, the collaboration of private enterprise, the dedication of a committed team and the efficient use of 
allocated resources. Its aim is to reduce the knowledge gap between the different sectors of society and meet the diverse needs of students, with special emphasis on those groups that are atrisk, excluded, or marginalized. The program responds to the learning needs of adults and especially educationally deprived women from urban and rural areas, who have little access to formal education.

There are many challenges ahead for the improvement of lifelong learning in Ecuador. In addition to new policies that support and sustain lifelong learning, it will be of benefit to rethink Aprendamos as a national widespread educational program. In this way, the program can serve as a bridge to help the citizens of the nation that have been left behind in their learning. It can provide a way for families to support the formal education of their children. It can enhance individuals' skills and thereby prepare them for better job opportunities. As a national program, Aprendamos could form part of a strategy for poverty reduction, in compliance with the OECD's (2006) Lifelong Learning for All objectives of "personal development, social cohesion and economic growth." Such educational reforms will empower citizens with a solid education and allow them to explore new fields of knowledge; they will be enabled to face the new challenges and conditions of modern life and technology, and find ways to reinvent themselves through a lifelong learning experience for their own human growth and development.

\section{Bibliography}

Mr. Roberto Vernnimen, Director of DASE. Personal Interview. 2014

Mr. Miguel A. Valdiviezo, Director of Fundacion Ecuador. Personal Interview. 2014

Bruni, J., Aguirre, N., Murillo, F., Diaz, H., Fernandez, A. \& Barrios, M. (2008). Una Mejor Education para Una Mejor Sociedad. Federacion Internacional de Fe y Alegria.

Centeno, V. (2011) 'Lifelong learning: a policy concept with a long past but a short history', International Journal of Lifelong Education vol. 30 No. 2, pp. 133-150.

Cohen, J. \& Arato, A. (1992). Civil society and political theory. Cambridge: MIT Press.

Congreso Nacional del Ecuador (1997). Ley de Descentralizacion del Estado y Participacion Social. $\quad$ Retrieved from: http://www.comaga.org.ec/index.php/component/docman/doc_download/5-ley-dedescentralizacion-del-estado-y-participacion-social?Itemid $=11$

Constitution of the Republic of Ecuador. (2008). Translated by Georgetown University. Retrived from http://pdba.georgetown.edu/Constitutions/Ecuador/english08.html

Dave, R.H. (1976) 'Foundations of Lifelong Education.', UNESCO Institute for Education and Pergamon Press, pp.132 http://aeq.sagepub.com/content/28/2/132.full.pdf

Delors, J. (1996). Learning, the treasure within: Report to UNESCO of the International Commission on Education for the Twenty-first Century. Paris: Unesco Pub. 
Faure, E. et al. (1972). Learning to Be. United Nations Educational, Scientific and Cultural Organization.

Field, J. (2006). Lifelong Learning and the New Educational Order, Stoke on Trent: Trentham Books.

Instituto Nacional de Estadísticas y Censos (INEC) de Ecuador. (2001). Resultados del censo 2001. Translated by the authors. Retrieved from http://www.ecuadorencifras.gob.ec/resultados/

Jarvis, P. (2006) 'Beyond the learning society: globalization and the moral imperative for reflective social change. International Journal of Lifelong Learning Education, 25:3, pp. 201-211

Murphy, M. (2001). The political economy of civil society: Implications for adult and community education. Conference Proceeding. Retrieved from: http://www.adulterc.org/Proceedings/2001/2001murphy.htm

Palmer, E. (1997) Television for Learning: Our Foremost Tool in the $21^{\text {st }}$ Century. UNESCO. Retrieved from: http://www.unesco.org/education/lwf/doc/portfolio/opinion7.htm

Presidencia de la Republica Ecuador (2010). Ley Organica de Educacion Superior. Retrieved from: http://uide.edu.ec/SITE/norma_juridica.pdf

Presidencia de la Republica Ecuador (2011). Ley Organica de Educacion Intercultural. Retrieved from: http://educacion.gob.ec/wp-content/uploads/downloads/2012/08/LOEI.pdf

Presidencia de la Republica Ecuador (2014) Reglamento para Operaciones de ONG'S en Ecuador, Decreto 16. Retrieved from: http://www.oas.org/juridico/pdfs/mesicic4_ecu_dec16.pdf

Secretaría Nacional de Planificación y Desarrollo (2013) Plan Nacional del Buen Vivir 20132017. Objetivo 4. 4 Retrieved http://documentos.senplades.gob.ec/Plan\%20Nacional\%20Buen\%20Vivir\%2020132017.pdf

Tight, M. (1998). Lifelong learning: Opportunity or Compulsion?. British Journal of Educational Studies, 46, 3, pp. 251-263.

Torres, R. (2005) 12 Tesis para el Cambio Educativo: Justicia educativa y justicia economica. Federacion Internacional de Fe y Alegria.

Walker, M. 2012. Egalitarian Policy Formulation in Lifelong Learning: Two models of Lifelong Education and Social Justice for Young People in Europe. Second International Handbook of Lifelong Learning, pp.181-192

World Bank (2015) Corporate Responsibility. Retrieve from: http://crinfo.worldbank.org/crinfo/social_responsibility/civil_society.html 